\title{
AERIAL ART, THE NEW LANDSCAPE OF ROBERT SMITHSON
}

\author{
Ramón PICO* \\ University of Seville, Hisoria, Teork̦a y Composición Arquitectónicas, \\ C/ Lucero, 2, Seville, 41003 Spain
}

Received 16 February 2018; accepted 15 March 2019

\begin{abstract}
Aircraft were to play a decisive role in the short career of Robert Smithson. In 1969, when he published his article Aerial Art, Walther Prokosch, an architect specializing in aviation, put him in contact with TAMS engineering. This gave rise to his involvement in a land altering operation as vertiginous and brutal as the construction of Dallas Fort-Worth International Airport.

At that point Smithson became aware of the human capacity to transform Mother Earth and the importance of contemplation from the air. He incorporated these interests into his artistic creation, thus paving the way for earthwork, crucial to the evolution of Land Art.

The study of the documents included among Robert Smithson's Papers at the Smithsonian Museum of American Art allows us to reconstruct a history that shared interests and concerns with Moholy-Nagy's New Vision or Le Corbusier's Loi du Méandre.
\end{abstract}

Keywords: land art, Robert Smithson, airports landscape.

\section{Introduction}

The aim of this article is to delve in the new relations that the aerial view brought to the architecture and landscape architecture after it's natural and progressive assimilation by the contemporary society by the middle of the $\mathrm{XX}$ century, in a double approach.

In a broader one, this article is aligned with a new vision of the landscape as a space of total urbanization, trying to explore the impact of aerial gaze on the perception of the human made landscape as a balanced part of a global habitat. The work of Robert Smithson, whose texts and artistic pieces were specially focussed on this, has been selected as case study, establishing a critical perspective far removed from the usual naive approaches to Smithson's work, in order to demonstrate his interest in leading the transforming power of twentieth-century man to a position of dialogue with the landscape.

In a closer approach this text will underline how the natural and progressive adaptation to the view from the heights has also had a significant impact on a transformation of contemporary architecture and landscape architecture, tending towards sculptural interpretations. In this sense, Smithson was recruited by TAMS engineers in order to figure out what could be a contemporary air- port. In this challenge, he understood that the aerial view should be an indispensable ingredient, and his design for the new terminal of Dallas Forth Worth airport, conceived as a giant sculpture it's the main demonstration on this, as can be clarified by the valuable and unpublished information found after two years working in the Robert Smithson files at Smithsonian Museum of American Art, that has been included in this article.

\section{Airports and the city}

Airports build the city, structure the landscape and should not be raised or perceived as a barrier. This was the firm belief of Walther Prokosch, who in 1949 produced Airport Planning, one of the texts of reference at that time. Prokosch's position was clear: "the connotation of the phrase on the other side of the rail road tracks should not and need never be applied to airports" (Froesch \& Prokosch, 1949, p. 18). From the beginning his career as an architect was linked to the world of aviation planning and in 1949 he joined the firm Tippetts, Abbett, McCarthy, Stratton, New York Architects and Engineers (TAMS), consultants for mobility and transport, specialized in the comprehensive planning of airports and major ports such as Chicago,

${ }^{*}$ Corresponding author. E-mail: rpico@us.es 
Anchorage or Aruba, works that undoubtedly had a great capacity to create new landscapes.

His text addresses conflicts and opportunities for territory resulting from the construction of an airport: the success of a plan for the implementation of a large airport infrastructure depends on its capacity to articulate a territory and to become part of its everyday life (Figure 1): "It will demonstrate the manner in which the entire phase of air transportation will be integrated with the daily life of the region under study" (Froesch \& Prokosch, 1949, p. 19). that is to say, its capacity to build landscape, drawing on the ideas expressed by Beardsley or Maderuelo (Beardsley, 1998; Maderuelo, 2008). Moving beyond the social plane, his text shows major concern regarding the development of information and educational materials. The promotion of participatory processes and the involvement of users in the daily use of these facilities also become part of an airport democratic pedagogy in which artistic readings play an important role as well.

His theories were gradually completed and clarified in the course of his fruitful career, which included participation in major projects such as the Pan American Terminal building at Kennedy International Airport 1960 (Figure 2). Pan Am was in fact the first company to order fleets of new Boeing 707s and 747s, aircrafts which revolutionized air travel thanks to their range, speed and above all, passenger capacity. This represented a total transformation, shifting from Jet Set to Jumbo People, from exclusive chic airports to large facilities dominated by management and circulation criteria (Gordon, 2004). Designed specifically for the new fleet of 747s, the extension of Pan Am Terminal, the largest in the world at the time, definitely showcased a trend toward gigantism and functionality for airports, a trend which reached its apogee with the facilities of Dallas-Fort Worth: "We're not building a monument, we are building a tool" (Sullivan, 1973).

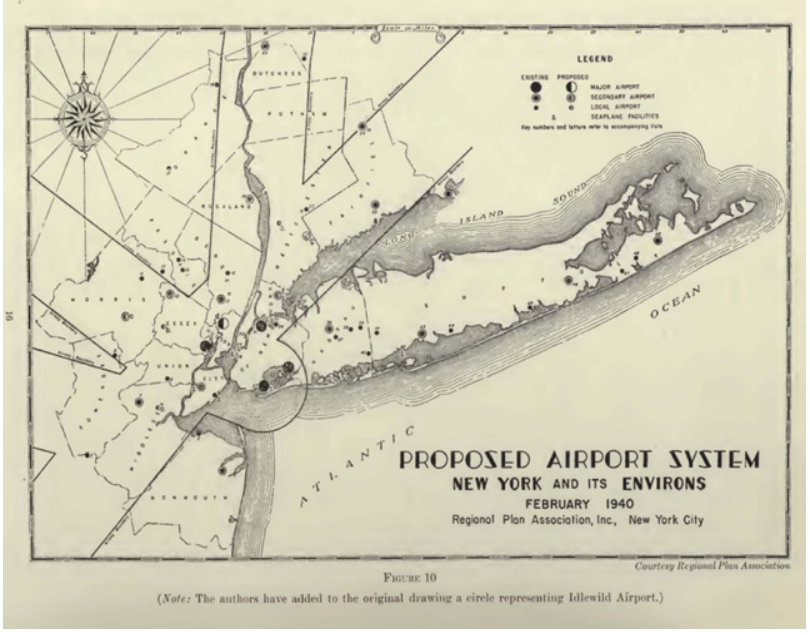

Figure 1. Walther Prokosch and Charles Froesch, Airport Planning (New York: John Wiley \& Sons, 1949), Figure 10

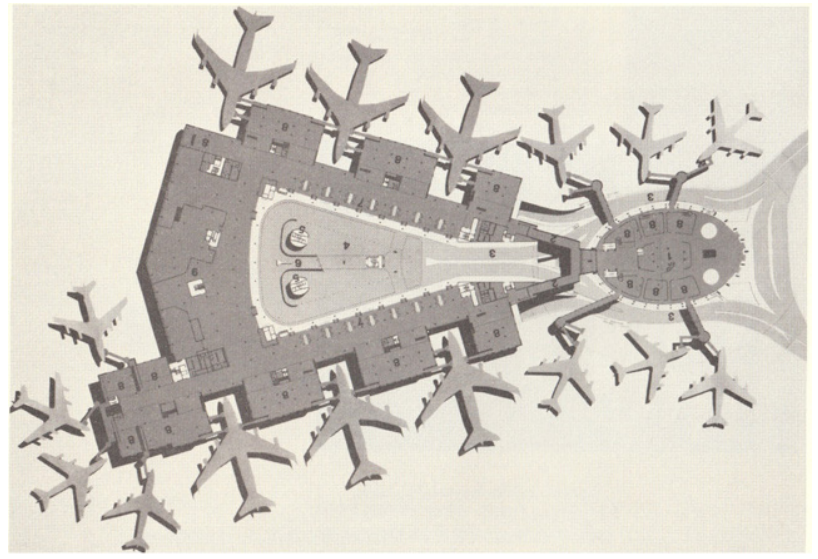

Figure 2. TAMS. Expansion of the Pan American Passenger Terminal at John F. Kennedy International Airport, Worldport, (1969-73), included in Detailed Design (1983), by Walther Prokosch

\section{Looking for innovative approaches to airport design}

On 17 June 1966 Prokosch attended a session in the School of Arts and Architecture at Yale University, organized by art critic Brian O'Doherty. Young artist Robert Smithson also participated in the session, entitled Art in the City. Prokosch must have been impressed by Smithson's conference, suggestively titled Shaping the Environment: The Artist and the City, which called for the city and territory to be understood as a single entity from an artistic perspective, as a new "crystalline network" (Smithson, 1966)

Smithson, always keen to explore, had begun to develop this perception of the landscape a few months earlier as a result of his regular and well known trips to the outskirts of New Jersey. Prokosch, interested in Smithson's approach, (Boettger, 2003) suggested him to participate as "artist-consultant" in the preliminary studies and conceptual development of Dallas-Fort Worth Airport, which was being hailed as "the biggest public works projects since the pyramids".

He also asked Smithson to go the extra mile in landscaping tasks which were becoming common in airports at the time (Figure 3). As Duempelmann accurately states (Duempelmann, 2010, 2014), experiences like Fairfax Airport in Kansas City marked the inclusion in airport design of innovative approaches which were attempting a shift from airports to airparks through the use of formal landscape design. At the time, there were tremendous contradictions in terms of form, with trimmed hedges and an obsession with perspectives and symmetries that verged on typically French ornate garden styles. Smithson's contribution to the DFW team aimed to be much more than a mere covering of vegetation. It also proved to be the necessary stimulus for a young artist who up until then had been under-valued.

Smithson was especially seduced by the scale of the interventions carried out by TAMS and the company's 


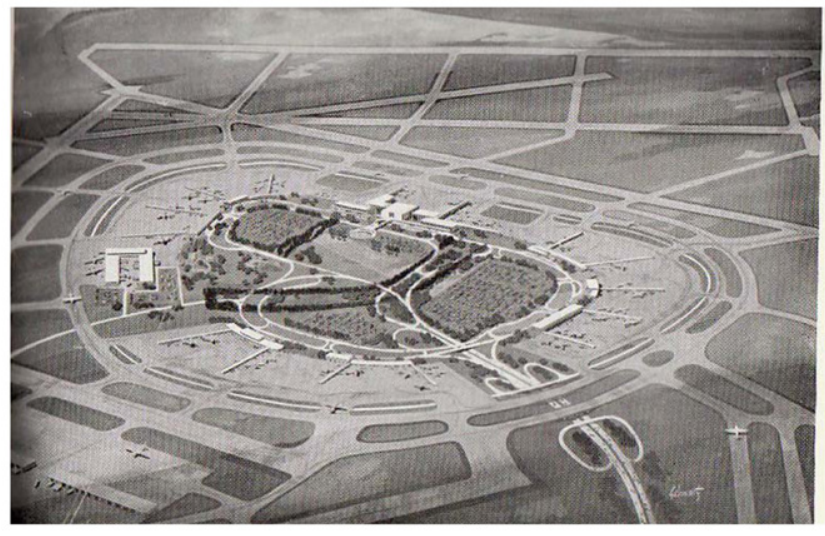

Figure 3. Eugéne Pépin, Géographie de la circulation aérienne, (1956): "Project d'artiste pour la zone central de l'aéroport, (Port of New York Authority)"

capacity to shape landscape through major port infrastructures, launching jetties into the sea, sectioning the shore or creating artificial territories. He also viewed the construction process as a dynamic artwork, conceived in different stages that fade over time, and the progress of the work as hugely suggestive. The overwhelming amount of information collected and generated throughout the process undoubtedly stimulated Smithson: geological guides containing the physical history of a place, topographical maps whose curves depict elevations and dips in the land, evidence from surveys that disclose the secrets inside the earth, hundreds of aerial photographs that reveal subtle textures and colors to the eye of the traveler... Smithson's gleeful immersion in this new world defined a turning point in his work and, ultimately, in the history of Land Art (Eggebeen, 2011).

Walther Prokosch was equally influential in this shift. In the months following July 1966 Smithson's diary was filled with meetings with the architect (RSP: 3832). In these, Prokosch's open and comprehensive understanding of city and territory and his interest in the pedagogical communicative effect of airport design made a strong impression on a particularly receptive Smithson.

It is essential to establish a critical perspective far removed from the usual naive approaches to Smithson's work in order to demonstrate the brutality of the events in which the artist was involved. Smithson came into contact with a land subjected to a savage transformation, both in terms of the magnitude and the urgency of the process. In less than thirty years, a pasture-filled landscape was transformed by stages into a conventional industrial estate. During this time, an airport with international pretensions and six-mile-long runways was developed and literally erased (Figures 4,5 ). It was a voracious process with obvious similarities to the dramatic transformation of Manhattan for which Koolhaas coined the term urban cannibalism, the wildest and most dramatic form of landscape construction.
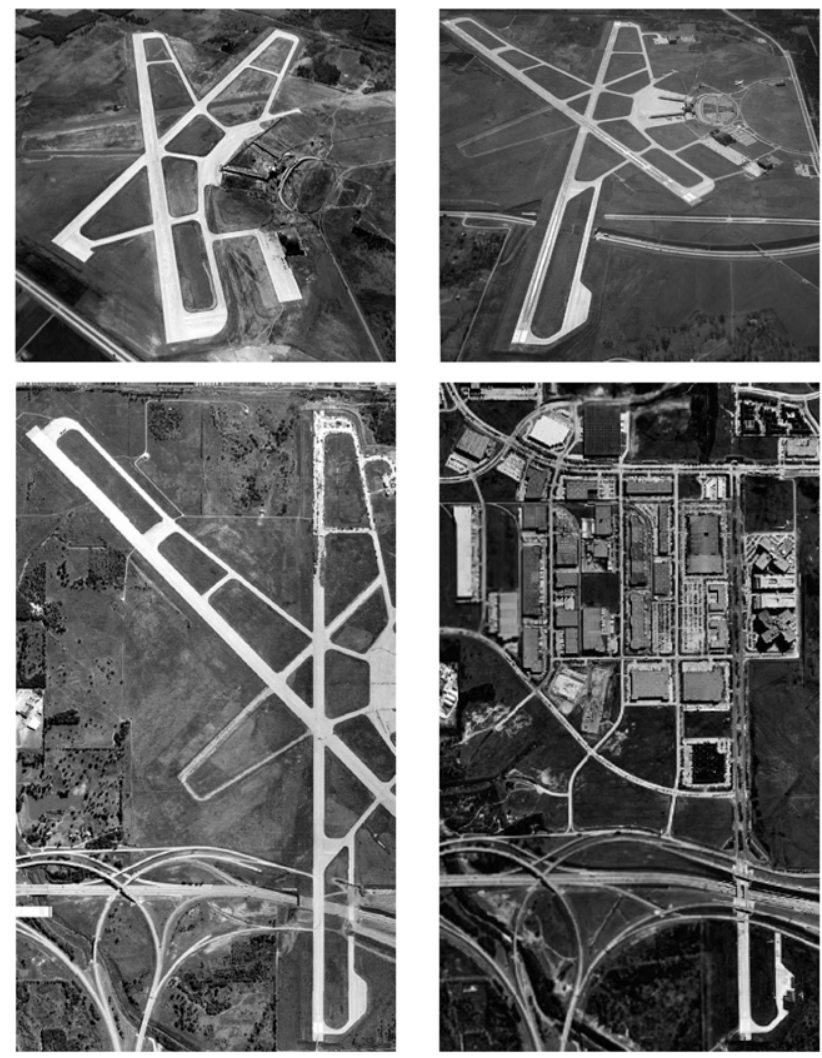

Figure 4. The aerial view show us a sequence of the frenetic transformation of Greater Fort Worth International Airport (note North is at the bottom): $1953 \mathrm{GFW}$ as renovation of Midway airport; 1968 GFW expansion; Ca 1975 GFW disassembly; Ca 1980, the main runway (17/35) was decommissioned to become Amon Carter Boulevard, the backbone of the new Centre Port industrial estate

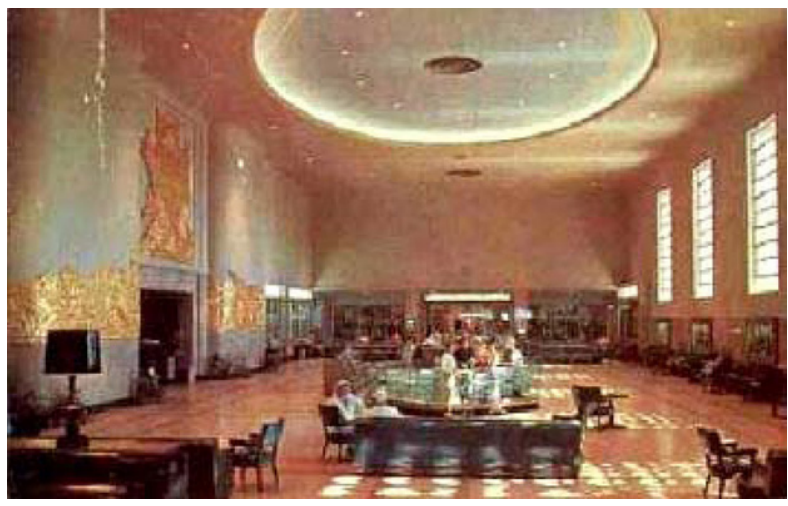

Figure 5. The Greater Fort Worth International Airport Deco Terminal (1953), demolished in 1980

\section{New world, new geometries}

In summer 1966 TAMS developed the Master Plan for the new Dallas / Fort Worth International Airport. Six huge runways stretched out over 17,000 acres of scattered buildings (Figure 6). Up till then, Smithson's career had been rather uncertain. After an initial introspective phase, he moved on to painting without much success with a solo exhibition of drawings held in the spring of 1961 at the 


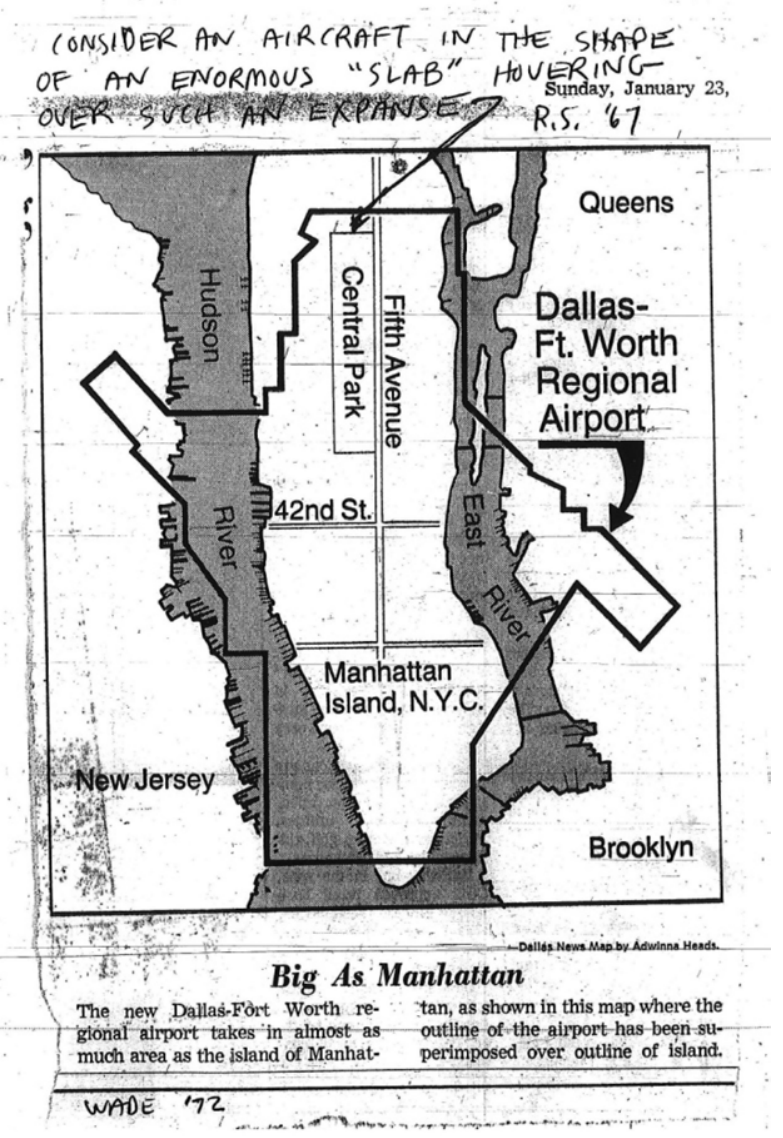

Figure 6. Robert Wade sent this clipping from the January 23th 1971 edition of Dallas Paper to Robert Smithson

George Lester Gallery in Rome (Figure 7). At this time the unexpected and lyrical quality of his work made it hard to predict what was to follow (RSP: Reel 3832, Frame 259)

After several disappointments and rejections, attributed to his showing "little character", his path came to be guided by his early pursuits. Since childhood he had been keen on exploration and collecting, totally fascinated with the world and its transformations. The land itself was to provide him with everything that he needed for his work to gain recognition from the MOMA. This reencounter with his earlier path initially took the form of various critical writings such as Crystal Land, concerned with the possibility of incorporating elements to express the harshness of reality and rough character of our world into the artwork, using unprocessed geological materials - dirt, dust, rocks- emphasizing the richness of their hues and textures contrasting with Judd's polished steel.

It is clear that these interests inevitably led to a reflection on the boundaries of the work of art and its relationship with place, at a time when the first outdoor displays of sculpture were taking place in the United States, such as the pieces by Calder, Moore and Smith: art had finally moved out of museums and progressively been integrated into daily life. This breaking loose asked for special efforts to locate areas where artistic actions could establish

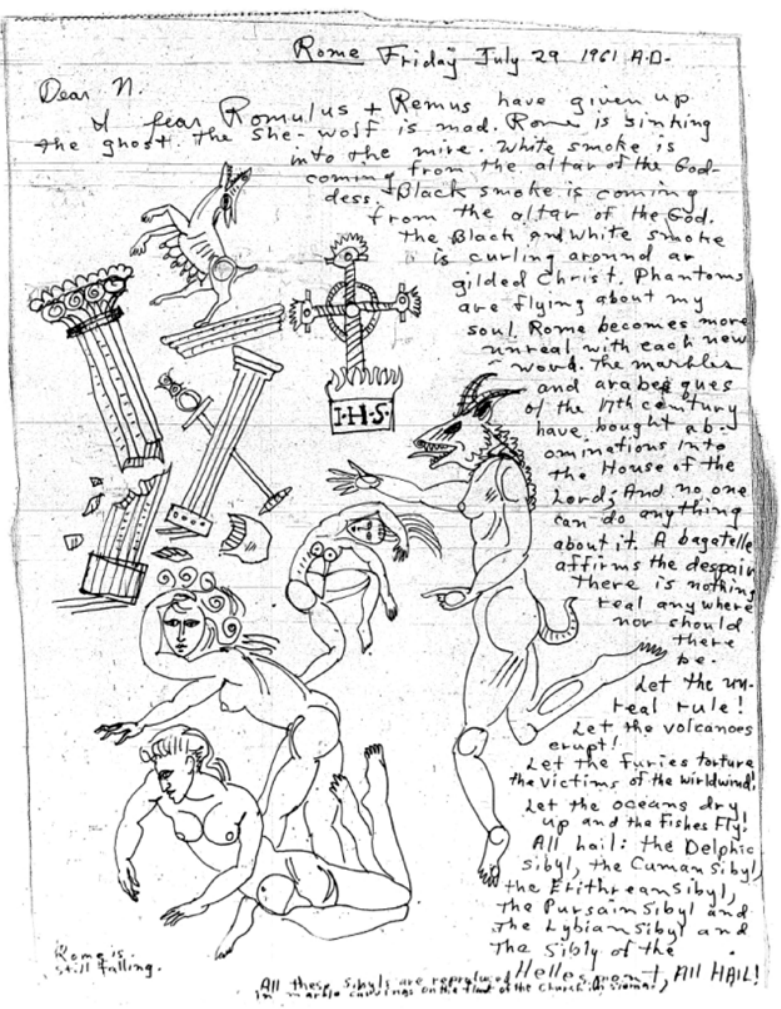

Figure 7. Robert Smithson, letter to Nancy Holt from Rome (1961) - RSP, Reel 3832

a synergistic relationship with place. The search for these new territories set the beginning of an inescapable artistic process in which the artist-explorer found new allies such as the light aircraft or the eyes of distant satellites.

The collaboration with TAMS between July 1966 and June 1967, added nuances and finishing touches to these interests, encouraging Smithson to consider three factors: the growing and disproportionate importance of human activity in landscape construction, the permanence and transience of this process, and the significance of the aerial view in the new vision of the world.

He immediately perceived the special conditions of runways, expansive spaces which provided with a great depth of field, and automatically prompted him to consider the scale and position of the works, looking for Clear Zones, places at a distance from airport installations which allow for good visibility during the plane's approach. Thus, aviation terminology comes to take part in the development of an artistic language, interested in the manipulation and the contemplation of the land from the air. Perception is closely linked to the flying experience in his initial sketches, since these places are always viewed from the air and never in a direct approach. Smithson experienced this from the vantage point of the copilot (Figure 8), raised on the runway, and this head-on approach, which is non-existent or fleeting for most passengers, played an important emotional role for him.

During the first months of work, the reconnaissance process was accompanied by some initial reflections on 


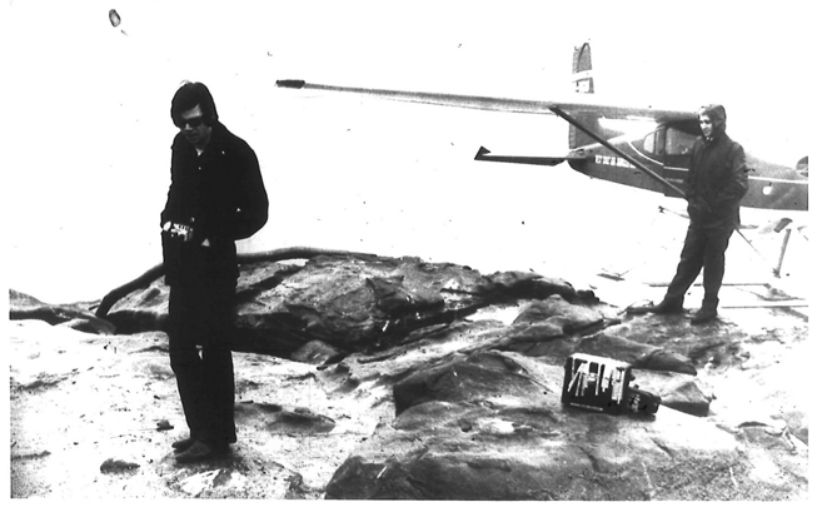

Figure 8. Robert Smithson preparing to take aerial pictures of Spiral Jetty in Salt Lake, Utah, 1970

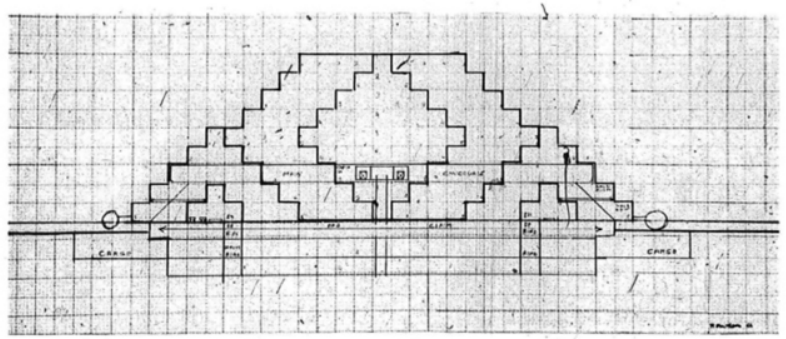

Figure 9. Robert Smithson, Airport Site Map, 1966

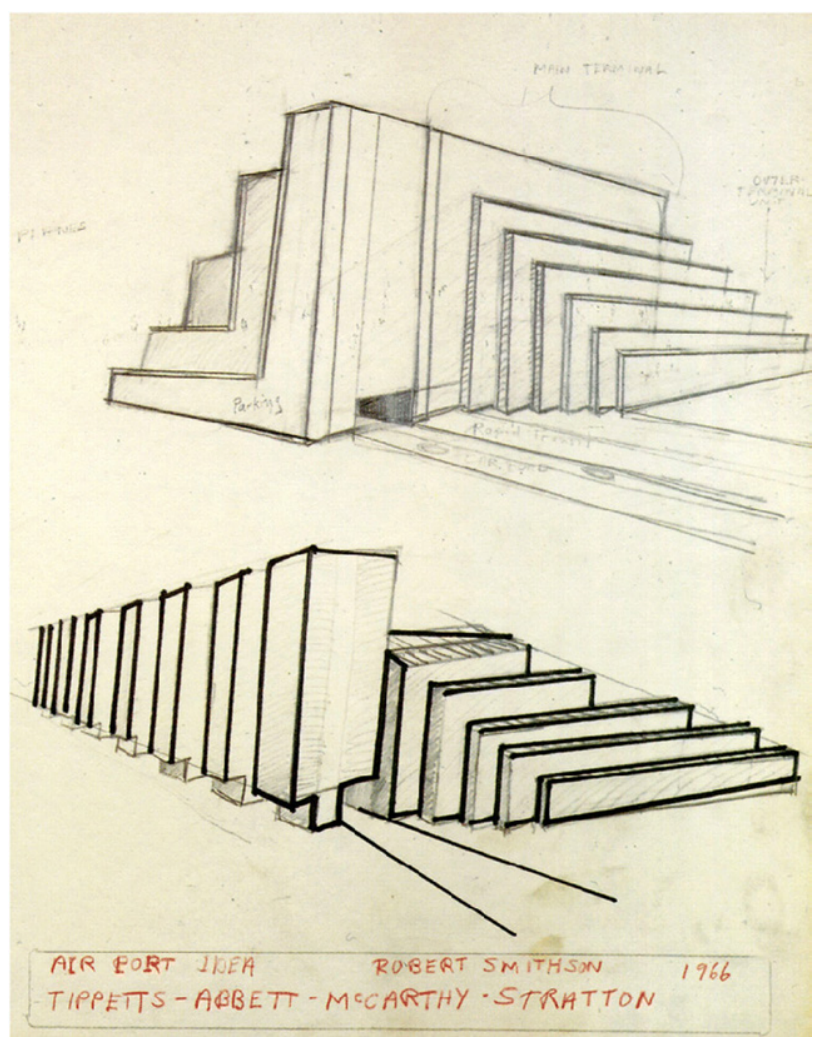

Figure 10. Robert Smithson, Airport Idea, 1966 the future passenger terminal. In late 1966 Smithson drew some initial sketches to define the volumes of the immense building, whose hugeness completely overwhelmed him: "The double white rectangles within the grid shall someday contain a series of terminals each one the size of Grand Central Station" (Smithson, 1969, p. 180). Smithson started with a general outline of the project plan prepared by TAMS, and was obsessed with the traffic flow dynamics that are a feature of these iconic communication centers. He used this outline as an initial guideline to be radically processed according to scale, perspective, serial order or geometric integrity, all elements to be found in his works Alogon or Plunge from the same year. Smithson's different drawings allow us to understand the process. Airport Site Map (1966) (Figure 9) features an outline of a sectional diagram of the terminal building which suggests levels of public spaces, interior voids, traffic and communications elements, etc. This section clearly corresponds to the staggered volumes of the drawing for Airport Idea (Tippets, Abbett, McCarthy, Stratton) (1966 (Figure 10))

Finally, these plans took on material form in the white steel model-sculpture Terminal (1966), heir to a series initiated by Alogon (1966), which introduced slightly rotated volumes, and continued in later works like Shift (1967) or Leaning Strata (1968). At that time the best-known airport work was represented by the photogenic TWA terminal of New York (1956-1962), in which Eero Saarinen resorted to an organic metaphor that is an excessively literal interpretation of animal flight (Figure 11). However, the definition of the terminal building proposed by Smithson expressed a clear desire to move away from this trend. As mentioned above, one of his main concerns was to delve into the ties between the world of aerospace and art in its broadest terms.

From his teens, Smithson had been a frequent visitor to the American Museum of Natural History, but he shifted his attention from dinosaurs and geology to focus on collections and exhibitions developed around the old Hayden Planetarium. He was especially interested in the SECOR satellite, as the works of Bell or Cubic Corporation, developers of the satellite, indicated a clear evolution toward pure crystalline forms. In this way, modern airliners increasingly resembled massive flying obelisks: "Perhaps aircraft will someday be named after crystals. As it is now, many are still named after animals, such as DHC 2 Beavers; Vampire T.; Chipmunk T. Mk. 20; Dove 85; Hawker Furies; Turkey; etc. At any rate, here are some names for possible crystalline aircraft: Rhombohedral T2; Orthorhombic 60; Tetragonal Terror; Hexagonal Star Dust 49; etc." (Smithson, 1969, p. 38).

Thus, the Smithson proposal for the terminal building became a kind of giant satellite, an immense crystal, a huge inhabited sculpture. Years later, in his Detailed Design, Prokosch included a project section which clearly recognizes this contribution (Figure 12). 

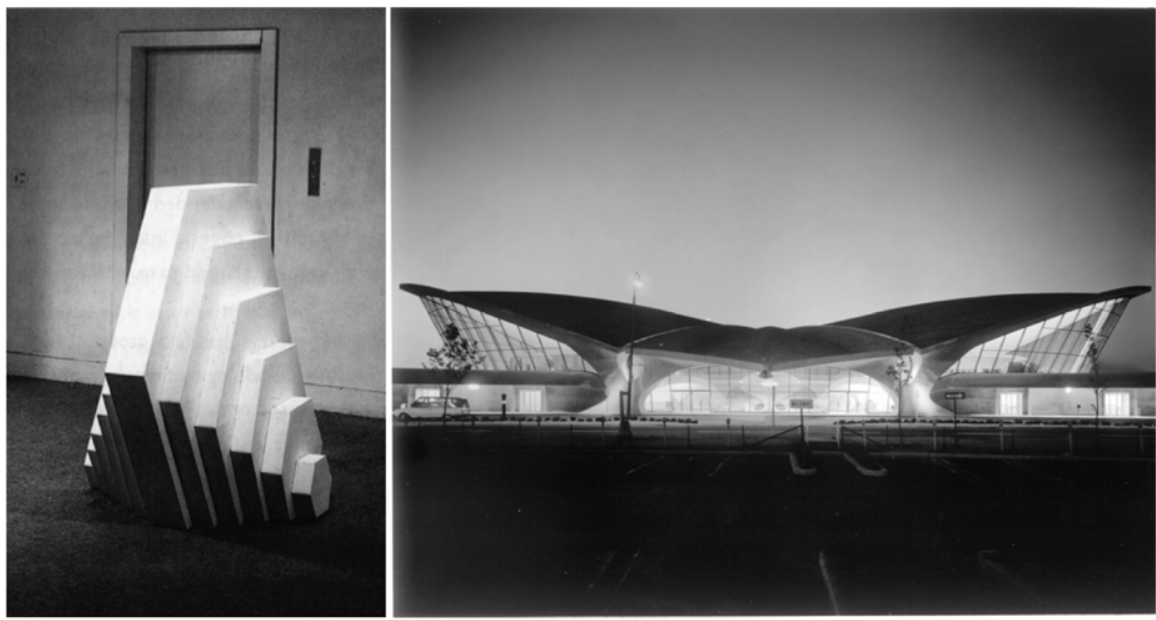

Figure 11. Robert Smithson, Terminal, 1966. This was the evolution of a 3d model of the DFW Terminal Building, totally different from the style of the TWA Terminal Building in JFK Airport (Eero Saarinen, 1956-62)

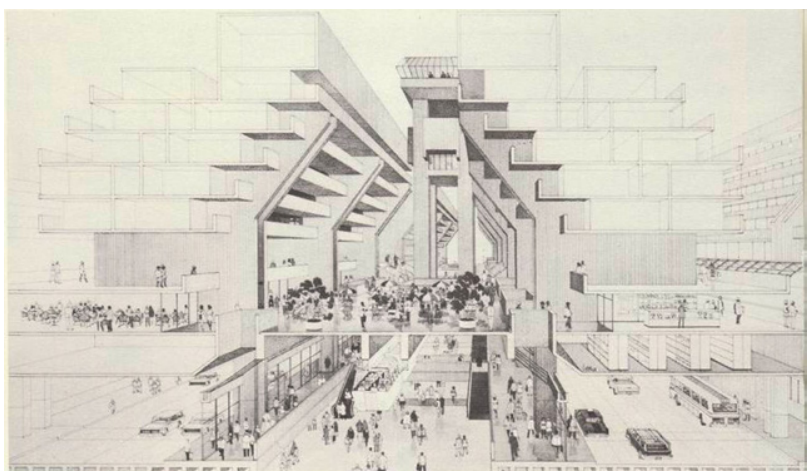

Figure 12. Project for the Terminal Building at DFW Airport,

(1966). Published by Walther Prokosch in Detailed Design (1983). The section is clearly related to the Smithson drawings, especially Airport Site Map

\section{From Top Art to Aerial Art}

Robert Smithson's relationship with TAMS ended in June 1967, but it had provided the conceptual foundations for the earthworks. Smithson started searching for other scenarios in which his work could develop (Figure 13). This new sensibility toward the values of the land and to the disclosure of its genetic code and scale was formally recognized as a new artistic path in what Boettger has identified as a milestone, the Sculpture in the Environment exhibition held in Central Park in the fall of 1967. When Sam Green was organizing this exhibition during the previous summer, Smithson had not yet produced any outdoor work, so he was only able to participate in it as a critic. However, later his work became central to the EARTHWORKS exhibition, held at Dwan Gallery from 5 to 30 October 1968. (Figure 14).

After the exhibition, his friend the editor Howard Junker, seeking media publicity, believed he had found the proper term to describe this new discipline which explores territories near topography: Top Art. "As a worthy successor of Op an Pop, Top Art is nothing less than topographical art. The Robert Rauschenberg of this art form is yourself. Walter de Maria is the Ad Reinhardt...." (RSP: Reel 3832. Frame 723).

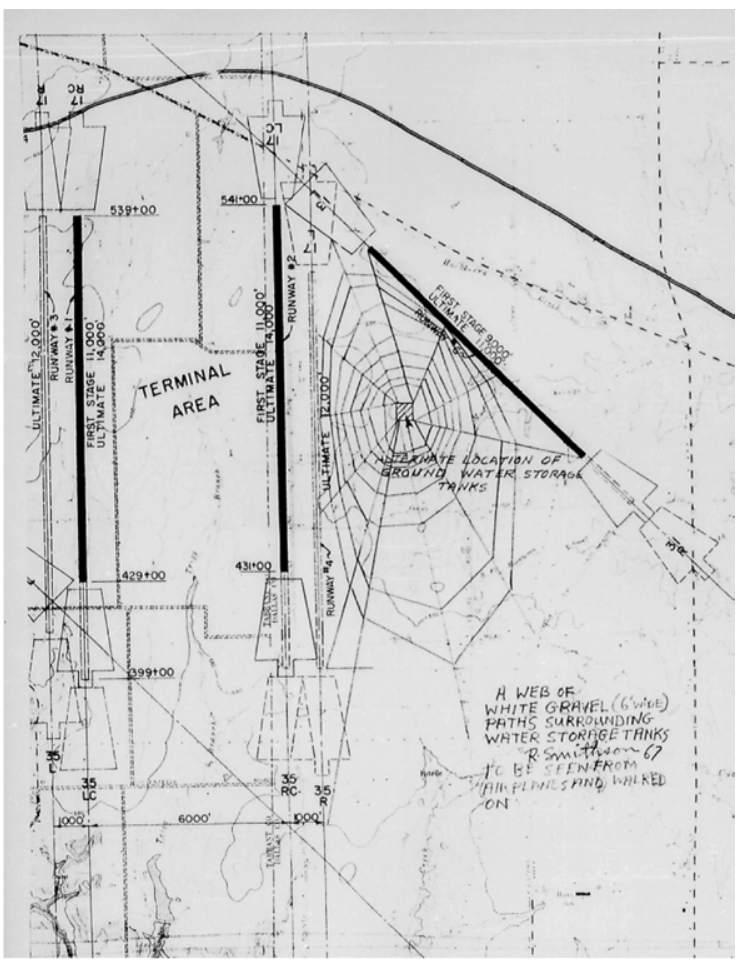

Figure 13. Robert Smithson, A web of White Gravel (1967). RSP, Projects, Reel 3834 Frame 299. Landscape design for the spaces between DFW runways, "to be seen from the air"
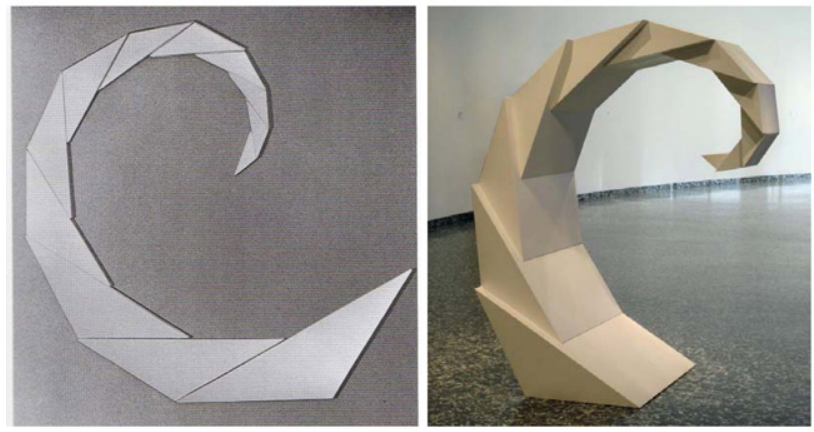

Figure 14. Robert Smithson, Aerial Map-Proposal for DFW Regional Airport (1967) and Gyrostasis (1967) 
In late 1968 Robert Smithson also received a personal letter from his friends Mike and Sharon: "Dear Bob and Nancy All animals have the ultimate desire for a private death. While life is spent in futile coordinates cravings, the back-brain tends towards searching out the conditions and situation of his place to die in.... place to finally attempt the final reflect, total relaxation" (RSP: Reel 3832. Frame 8/68)

This letter reveals the clear interest of Smithson's circle of friends in what is now described as the return to Mother Earth. Reclaiming the earth involved violation, a virgin sacrifice to extract and explain its inner treasures. This sacrifice took place within the framework of the DFW experience: the tools Smithson used in reconnaissance of the
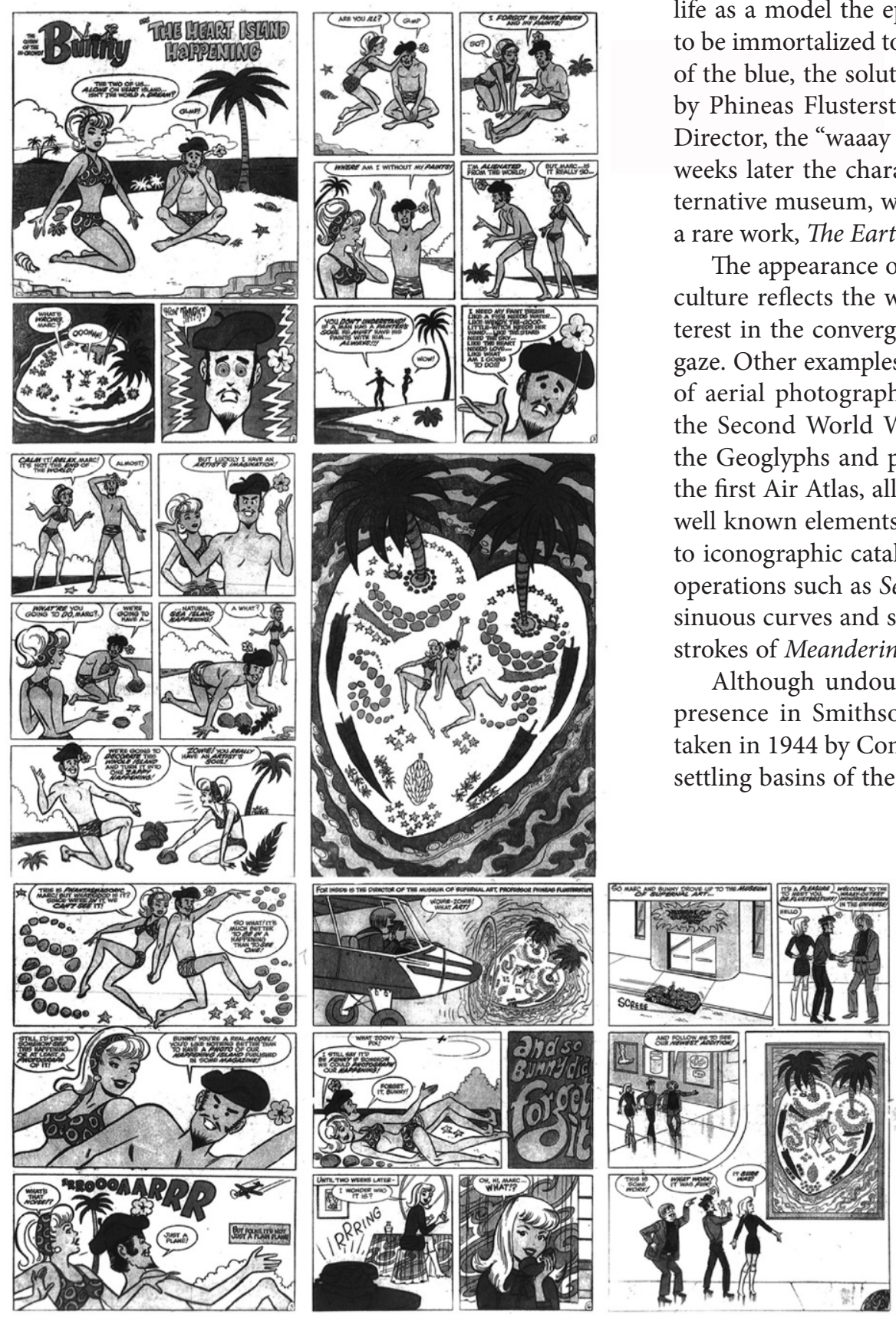

Figure 15. "The Heart Island Happening” (December 1968 issue of Bunny, the Queen of the in-crowd) sent to Robert Smithson by his friends Mike and

Sharon. RSP Reel 3834, Frames 25-30 site and the abstract and remote interpretation of the site provided by aerial reconnaissance are all decisive factors.

Mike and Sharon attached the comic strip The Heart Island Happening from the December 1968 issue of Bunny, the Queen of the in-crowd to their letter (Figure 15).

The script is revealing. Bunny, the famous supermodel star of the series, spends a day of love and relaxation in the solitude and isolation of Heart Island with her boyfriend, bohemian artist Marc. As the comic's title indicates both belong to the in scene of their respective worlds. However, the initial dream fades and descends into crisis, Marc has forgotten his brushes: "I need my paint brush like a fish needs water". The artist's imagination suggests a solution: to convert the island into a zappy happening in which flowers, palm trees, rocks and they themselves compose a brilliant work. Afterwards, Bunny gets depressed. In her life as a model the ephemeral is meaningless, so it needs to be immortalized to launch it to the media universe. Out of the blue, the solution appears as a small plane, piloted by Phineas Flusterstubb, the Museum of Supernal Art's Director, the "waaay outest museum in the universe". Two weeks later the characters are invited to the achingly alternative museum, which to Bunny's satisfaction includes a rare work, The Earth Island Happening, in the collection.

The appearance of a subject like this in popular comic culture reflects the widespread social and intellectual interest in the convergence of land construction and aerial gaze. Other examples of this are the extensive publication of aerial photographs of the Peruvian Nazca lines after the Second World War, the proliferation of writings on the Geoglyphs and primitive cultures, the publication of the first Air Atlas, all of which offered surprising facets of well known elements or adding new and fascinating ones to iconographic catalogs. Therefore Smithson's interest in operations such as Serpent Mound in Ohio it's clear as it's sinuous curves and spiraling tail are clearly echoed in the strokes of Meandering Island (1971).

Although undoubtedly even more interesting is the presence in Smithson's Papers of an aerial photograph taken in 1944 by Compañía Mexicana Aerofoto S.A of the settling basins of the Sosa Texcoco company in the north

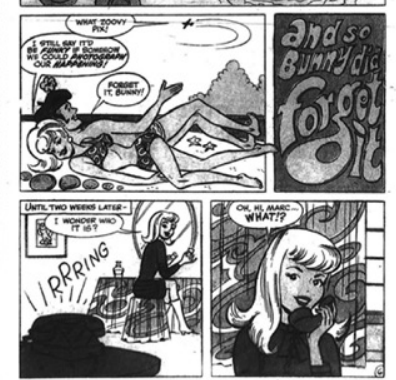


of Mexico DC (Figure 16). The name by which this area goes says it all: El caracol. Like many salt marshes, it is a harsh territory, dominated by sun and the horizon. The variety of crystals formed during the industrial process for producing salt, together with the different stages of evaporation, gives rise to a rich palette of colors which pass completely unnoticed by the passer-by. However, the salt marsh is a powerful image when seen from above, as Smithson clearly recognized: "Just how we should look at art is a question that is rarely considered. Simply looking at art at eye-level is no solution" (Smithson, 1969, p. 181).

However, El caracol also harbors another obsessive value: the spiral shape that interested Smithson for its ability to reflect both the infinite and loss of scale, as can be seen in his 1968 letter to Enno Develing. It thus became the perfect reference for the work that would raise Robert Smithson to the upper echelons of art, even transforming him into a media figure: his spiral jetty in the Great Salt Lake of Utah, a work which he had been preparing since 1968.

Spiral Jetty's production in 1970 was preceded by an extremely heterogeneous and complementary research, in search of a precise location. Topographical maps, geological yearbooks of the area, notebooks of prehistory and paleontology, cadastral surveys, road maps... noted the venue, which combined mineral wealth and historical support with a measure of balance between isolation and accessibility: Rozel Point. As at El caracol, the transformation of the line where water meets the land (Figure 17), the clear geometries and exciting colors of evaporation crystals and the hypnotic spiral became the keys to the generation of a powerful manipulation of landscape.

Smithson's aerial art operations go far beyond Howard Junker's concept of Top Art. In these, the process of modeling a topographical work incorporates both a preoccupation with time and an intellectual process. In this sense,

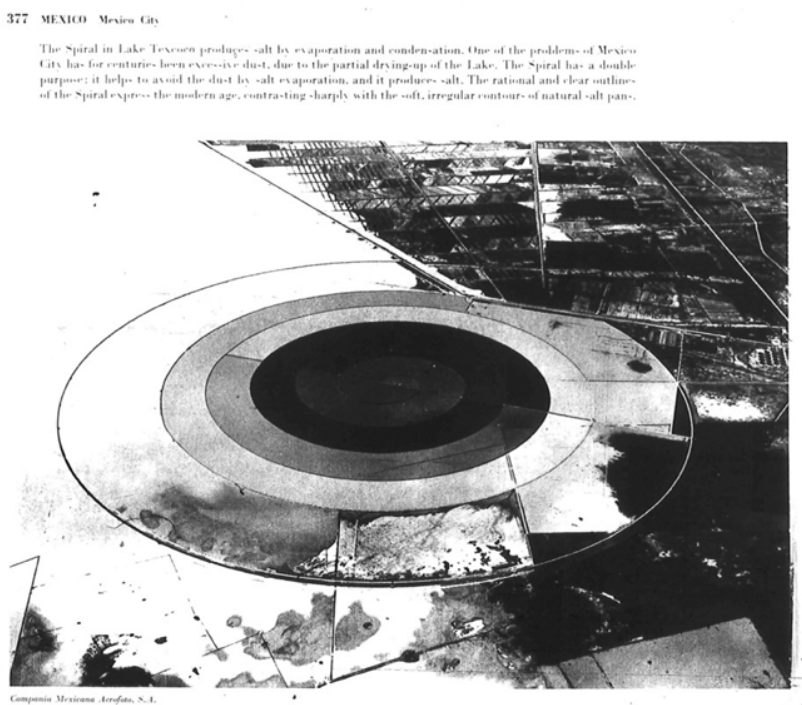

Figure 16. The spiral shape: an aerial view from the Sosa Texcoco company settlings basins in the north of Mexico DF (1944), in the archives of Smithson. RSP Reel 3835, Frame 967

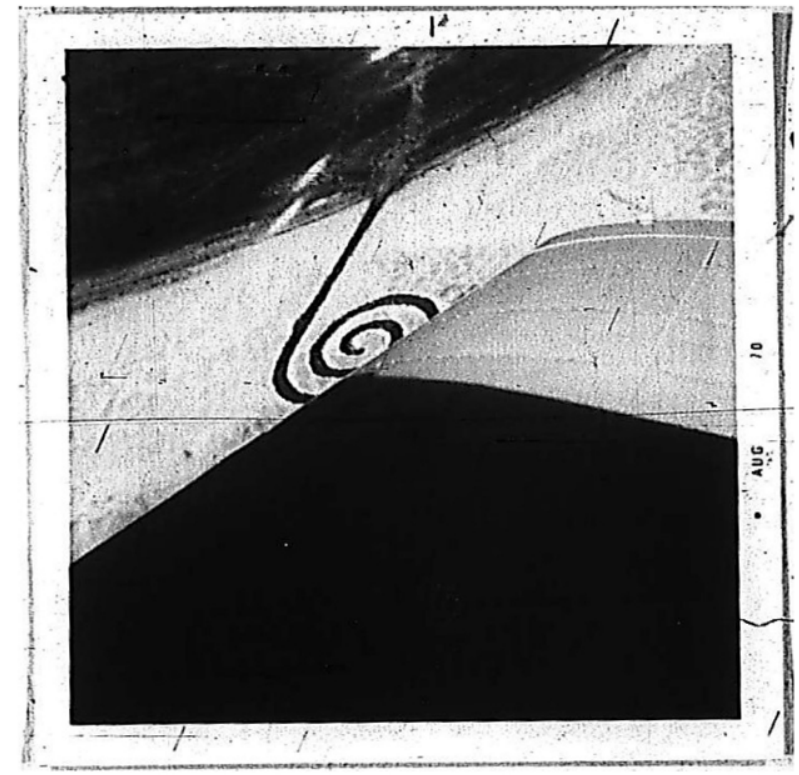

Figure 17. Robert Smithson, Spiral Jetty seen from the plane (Aug, 1970), RSP Reel 3835, Frame 1044

the integrity of Spiral Jetty is expressed in the uncompromising assessment of his film The Spiral Jetty, put together in December 1970 by Smithson with the help of Bob Fiore and Barbara Jarvis, on returning to New York, "the urban desert". The camera moves from the air, the waves caused by the rotation of the blades, even the dramatic 'fall' of the shadow of the helicopter to the ground are cinematographic devices which contribute to the understanding of the work as a whole. From then on navigation maneuvers ceased to be a mere instrument of exploration and were consciously incorporated into Smithson's artistic expression. This can be seen in the scripts for some works of this time, where the movement of planes, helicopters, trucks or tractors joined the cast to be eventually described as an essential mechanism.

In April 1969 he published Aerial Art, which brought together the theoretical crystallization of this whole process. Although written between 1966 and 1967, the article clearly and accurately reflects Smithson's thinking at the time of publication. Drafts for publication were carefully edited, annotated, completed and updated. The text was published by The Studio, which in 1935 started a collection inspired by The New Vision, the English edition of the Bauhaus book Von Material zu Architektur by Laszlo Moholy-Nagy (Moholy-Nagy, 1929). The first volume to be published was Aircraf, by Le Corbusier (Le Corbusier, 1935), which examined the momentous contribution of aviation to architecture, a fascination initiated in Paris, further developed in Buenos Aires (Collins, 1995, Gutiérrez, 2009) and crystallized in Urbanisme et Aéronautique, a more comprehensive vision of the surface of the earth (Le Corbusier, 1947).

Throughout the pages of Aerial Art, Smithson insists on the importance of the conquest of the territory by an artistic experience that has definitely abandoned architec- 
tural supports to meet the challenge of a landscape that will never be just natural. And it is airport environment that best contribute to making this task visible: "How art should be installed in and around an airport makes one conscious of this new landscape." This construction of landscape starts from a new understanding of it, leaving far behind the traditional gardening familiar to Smithson to venture into a conceptual stage backed by the references to mapping and engineering that gave meaning to the construction of the new terminal: "The future air terminal exists both in terms of mind and thing. It suggests the infinite in a finite way. The straight lines of landing fields and runways bring into existence a perception of "perspective" that evades all our conceptions of nature. The naturalism of seventeenth-, eighteenth- and nineteenth- century art is replaced by non-objective sense of site. The landscape begins to look more like a three dimensional map than a rustic garden".

The planned construction of this new landscape was certainly comparable to experiences promoted by Renaissance patrons, and was deliberately and consciously driven by the construction of the airport facilities. It is interesting in this respect that the execution of work does not contemplate the result as its ultimate and necessary goal: perhaps it can only really be fully understood or discovered from the air: "The outer limits of the terminal could be brought into consciousness by a type of art, which I will call aerial art, that could be seen from aircraft on takeoff and landing, or not seen at all." The text goes on to describe the development of the process, techniques and parts, defining for example the role of Clear Zones or the links between site and nonsite which transform the terminal into an art gallery.

Spiral Jetty was undoubtedly the most fertile and immediate result of this new means of expression. Jan van der Marck describes the aerial view of the work in a letter to Smithson on 16 June 1971. He excitedly tells how he had approached the Salt Lake in a small plane rented from the Air Utah company: "The flight over the Salt Lake was incredible as you know, I am sure. First the marshes with their sickly green and yellow colors. Then a flight over brown mountains where buffalo grazed. Then those salt basins with their varying minerals, neatly delineated, causing the water to range from a burgundy red to a mint green, a dirty white or a pale blue. I also delighted in the railroad dams across the lake. I never saw so many strange earth configurations, or mysterious tracks on the sands... I am sure you must have seen similar sights in the many days you were out there first finding the location, then making the piece. [...] I understood why you wanted to execute the work in that location and how much it approaches those other puzzling works of nature you see around there. In fact, the first thing my pilot remarked when we finally sighted the Jetty was: "You mean that was done by somebody?"' (RSP: Reel 3833. Frame 456). Van der Mark, an expert critic, was absolutely overwhelmed by the engagement of the piece, downplaying the geometric perfection of the work, usually one of the values assigned to it "from the air looks less geometrically precise than I expected."

Despite the undisputed success of his work, Smithson's original intention to transform the landscape of airports was not totally successful. After the frustrating experience of DFW he would not have time to carry out this type of work at any airport, although there were some attempts, attempts such as the one in February 1972 when Simone Swan suggested to Ann Holmes, editor of the influential Houston Chronicle, in a letter that she promote work by Smithson for Houston Airport: "Can you IMAGINE seeing it from afar you approach, then on landing? And seeing it as you drive to and from? And Houston being the first to boast of a readily visible Smithson (Salt Lake and the Zuider Zeee are more remote)? Let's do it together. OK?" (RSP: Reel 3833. Frame 981). After receiving a detailed map of the airport the same month, Robert Smithson actually began this project but his tragic death soon afterwards put an end to it.

\section{Crash}

In 1973 Smithson died in a plane crash on a reconnaissance flight over Amarillo (Texas) when examining the property of Stanley Marsh in search of the ideal place to locate what would eventually be his posthumous work, Amarillo Ramp. Smithson had previously carried out a thorough ground survey of the property, accompanied by the eccentric Marsh, who clearly described the artist's attitude to the place: "Smithson looked all over the property [...] We drove for weeks. He picked this spot. I thought it was one of the most unattractive parts of our land, but he said he didn't want to compete with nature".

Adventurous as ever, Smithson got on the plane on Friday 20 July ready to finish the work. The report on the accident clearly reflects that it was caused by maneuvers over the area been photographed: "Diverted attention from operation of aircraft. Photographing sculpture site". These maneuvers were undoubtedly carried out with a view to preparing Smithson's work Broken Circle / Spiral Hill: an untitled sketch dated 1971 indicates the work as being documented by a camera mounted on a plane doing a double figure of eight.

\section{Conclusions}

Despite his unfinished works, as time passes, it seems important to emphasize the need to analyze Smithson's interventions and theories from his interest in leading the transforming power of twentieth-century man to a position of dialogue with place and the transmission of the meeting of city and territory.

His contribution joins a line of fascination with contemplation from above that seems always to have been a characteristic of human beings, and which experienced a particular boost in the early twentieth century with the development of aeronautics; some of its most remarkable episodes are in the aerial cities of Italian Futurism, in the 
sketches and writings of a young Le Corbusier fascinated by flying machines or in Fuller's flying towers, all of them rigorously analyzed by Duemmpelman, Whol, Boyer, Cohen, Forman, Maderuelo or Morshed (Morshed, 2004).

After trying to find new ways for the contemporary art by recovering the links with the Earth, he coined a new name, Aerial Art, trying to underline the meaning of the new relations between man and earth by means of the sky (Figure 18). The use of aerial views, broadly found in it's files as references for its most relevant pieces, such as Spiral Jetty, and his persistence in flying experiences as part of the creative process, are the main demonstration of this links.

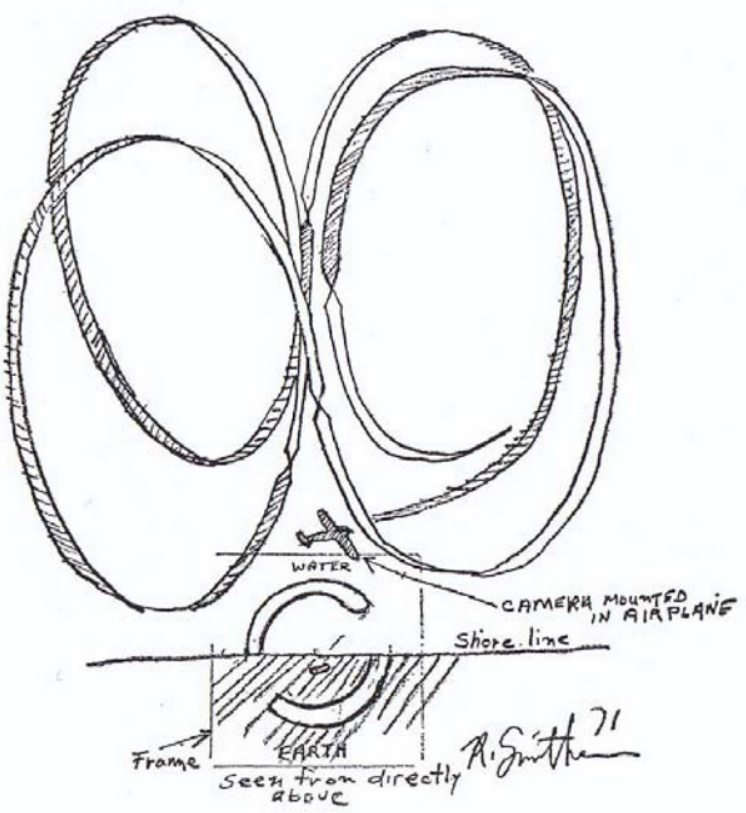

Figure 18. Robert Smithson, preparatory drawings for aerial shootings for Broken Circle, 1971
Furthermore, the natural and progressive adaptation to the view from the heights has had a significant impact on the sensory perception of the territory surrounding us as part of a global hábitat, but also and simultaneously on a transformation of contemporary architecture, tending towards sculptural interpretations.

Smithson's work anticipates a time when the new perception of reality, taken as an argument by Laszlo Moholy-Nagy in trying to establish the foundational training of future generations of artists and architects in the Bauhaus, has become a fact the contemporary author can't escape. His designs for the new Terminal building at Dallas Forth Worth airport, directly linked with his sculpture Terminal (1966), shows a new way of understanding the architecture, were the entire building became an immense crystal, a huge inhabited sculpture whose internal spaces scrupulously respected the functions, movement and specialty dictated by the initial outlines of the engineers (Figure 19).

In this new understanding of the project, boundaries between architecture and sculpture are blurred. We see this in the recent architecture, namely a special interest in visual art and processes of translation and / or scaling of shapes and composition mechanisms that populate our cities and flood the pages of the media with inhabited works in the style of Lootz, Smith, Oteiza, Holtz... or Smithson, as we can clearly see in recent works of relevant architects as Rem Koolhaas, Jacques Herzog or MGM.

\section{References}

Beardsley, J. (1998). Earthworks and beyond: contemporary art in the landscape. New York: Abbeville Press.

Boettger, S. (2003). Earthworks: art and the landscape of the sixties. Berkeley: University of California Press.

Boyer, M. C. (2003). Aviation and the aerial view: Le Corbusier's spatial transformations in the 1930s and 1940s'. Diacritics, 33(3/4), 93-116. https://doi.org/10.1353/dia.2006.0004

Collins, C. (1995). Urban interchange in the Southern Cone: Le Corbusier (1929) and Werner Hegemann (1931) in Argen-

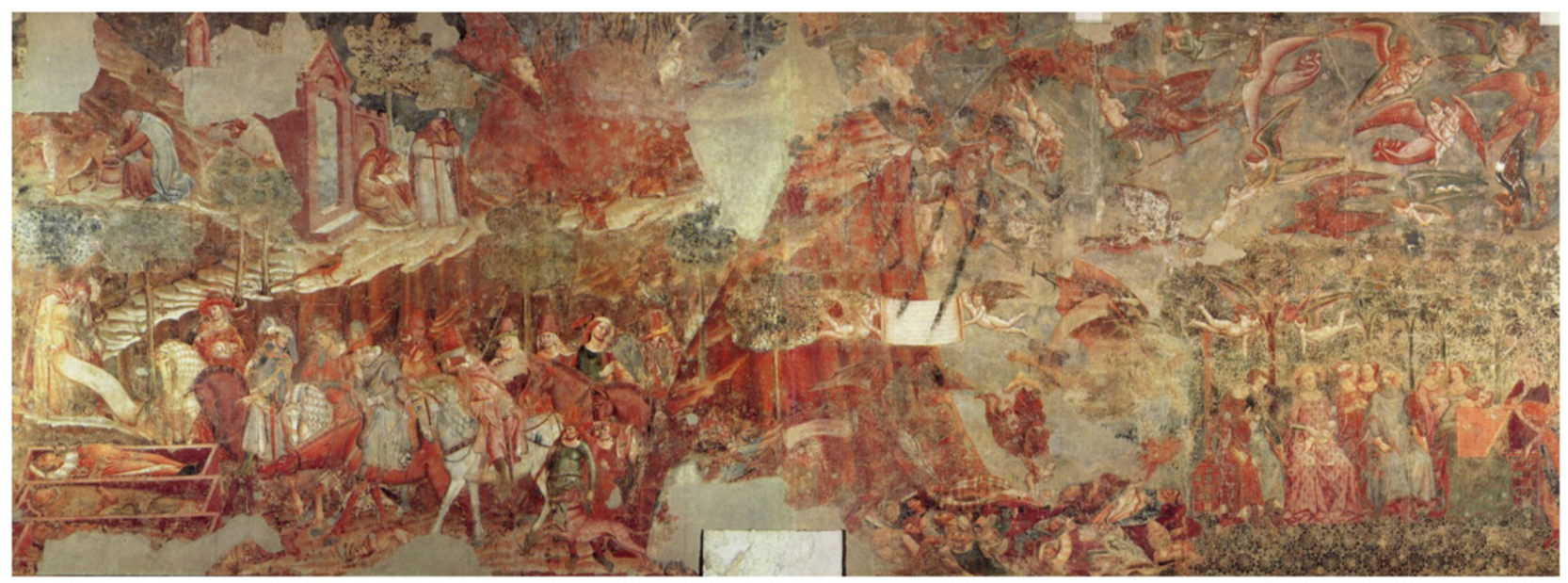

Figure 19. Buanamico Buffalmacco, Il Trionfo della Morte (ca 1330). Le Corbusier used a fragment of the fight between angels and devils in an overcrowded sky in his paper "Urbanisme et aéronautique" (1947), with the text "Nous avons connu déjà le ciel de Paris rempli du vrombissement des quadrimoteurs. Sur mon toit-jardin, quand l'un d'eux passait, il fallait cesser de parler...”) 
tina. Journal of the Society of Architectural Historians, 54, 2, June. https://doi.org/10.2307/990968

Duempelmann, S. (2010). Between science and aesthetics. Aspects of "Air-minded" landscape architecture. Landscape Journal, 29, 161-178. https://doi.org/10.3368/lj.29.2.161

Duempelmann, S. (2014). Flights of imagination: aviation, landscape, design. Charlottesville: University of Virginia Press.

Eggebeen, J. (2011). Between two worlds: Robert Smithson and aerial art. Public Art Dialogue, 1(1), 87-11. https://doi.org/10.1080/21502552.2011.536712

Froesch, C., \& Prokosch, W. (1949). Airport planning. New York: John Wiley \& Sons.

Gordon, A. 2004. Naked airport. New York: Metropolitan Books.

Gutiérrez, R., \& González, N. (2009). Hace 80 años, Le Corbusier en Asunción. Abc (Asunción, Paraguay), August 2th.

Hobbs, R. (1981). Robert Smithson: sculpture. Ithaca - London: Cornell University Press.

Le Corbusier. (1935). Aircraft. London: Studio Publications.

Le Corbusier. (1947). Urbanisme et aéronautique. Techniques et Architecture, VII(9-12), 463-467.
Maderuelo, J. (2008). La Construcción del Paisaje Contemporáneo. Huesca: CDAN.

Moholy-Nagy, L. (1929). Von Material zu Architektur. Dessau: Bauhaus Bauhausbuch 14.

Morshed, A. (2004). The aesthetics of ascension in Norman Bel Geddes's Futurama. Journal of the Society of Architectural Historians, 63(1), 74-99. https://doi.org/10.2307/4127993

Prokosch, W. (1983). Detailed design. Cambridge: Chimera Press. RSP. Smithsonian Museum, Archives of American Art. Robert Smithson and Nancy Holt Papers, 1952-1987. Unpublished.

Sullivan, T. (1973). Dallas/Fort Worth - a giant among airports. Airport Forum, 2, 37.

Smithson, R. (1966). The crystal land. Harper's Bazaar, May.

Smithson, R. (1969). Aerial art. Studio Internacional, 89 (February-April), 180.

Smithson, R. (1962-71). Robert Smithson's Papers, Smithsonian Museum of American Art. Washington D.C. Reel 3832.

Whol, R. (1994). A passion for wings: aviation and the Western imagination: 1908-1918. New Haven, London: Yale University. 